\title{
Does the Integrated Health Post have Contextual Effect on Exclusive Breastfeeding? A Multilevel Evidence from Karanganyar, Central Java
}

\author{
Lathifah 'Arub'), Eti Poncorini Pamungkasari²), Yulia Lanti Retno Dewi²) \\ 1)Masters Program in Public Health, Universitas Sebelas Maret \\ 2) Faculty of Medicine, Universitas Sebelas Maret
}

Background: Breastfeeding provides amazing benefits for the health of the child and the mother. WHO and UNICEF suggest a mother should be able to practice and maintain exclusive breastfeeding during the first six months of her baby's life. This study aimed to analyze contextual effect of integrated health post on exclusive breastfeeding.

Subjects and Method: This was cross sectional study conducted in 25 integrated health posts (posyandu) in Karanganyar, Central Java, from August to September 2019. A sample of 200 nursing lactating mothers who had children aged 7 to 12 months was selected by stratified random sampling. The dependent variable was exclusive breastfeeding. The independent variables were maternal age, education, occupation, type of birth delivery, knowledge, attitude, family support, and social capital. The data were collected by questionnaire. The data were analysis by multilevel multiple logistic regression with Stata 13.

Results: Exclusive breastfeeding increased with maternal age 20 to 34 years $(b=2.38 ; 95 \% \mathrm{CI}=$ 0.62 to $4.15 ; \mathrm{p}=0.008)$, maternal education $\geq \mathrm{se}-$ nior high school $(\mathrm{b}=1.64 ; 95 \% \mathrm{CI}=0.01$ to 3.23 ; $\mathrm{p}=0.049)$, good knowledge $(\mathrm{b}=2.13 ; 95 \% \mathrm{CI}=$ 0.41 to $3.86 ; \mathrm{p}=0.015)$, positive attitude $(\mathrm{b}=1.67$; $95 \% \mathrm{CI}=0.10$ to $3.23 ; \mathrm{p}=0.036$ ), strong family support $(b=1.58 ; 95 \% \mathrm{CI}=0.10$ to $3.07 ; \mathrm{p}=$ 0.036), and strong social capital $(b=1.64 ; 95 \%$ $\mathrm{CI}=0.01$ to $3.27 ; \mathrm{p}=0.049$ ). Exclusive breastfeeding decreased with mother working outside the house $(b=-3.54 ; 95 \% \quad C I=-5.50$ to -1.58 ; $\mathrm{p}<0.001)$ and section caesarean $(\mathrm{b}=-1.88 ; 95 \%$ $\mathrm{CI}=-3.58$ to -3.58 to $-0.19 ; \mathrm{p}=0.029$ ). Integrated health post had strong contextual effect on exclusive breastfeeding with intra-class correlation $($ ICC $)=29.3 \%$.

Conclusion: Exclusive breastfeeding increases with maternal age 20 to 34 years, high maternal education, good knowledge, positive attitude, strong family support, and strong social capital. Exclusive breastfeeding decreases with mother working outside the house and section caesarean. Integrated health post has strong contextual effect on exclusive breastfeeding.

Keywords: exclusive breastfeeding, multilevel analysis, posyandu

\section{Correspondence:}

Lathifah 'Arub, Masters Program in Public Health, Universitas Sebelas Maret, Jl. Ir. Sutami 36 A, Surakarta, Central Java 57126. Email: lathifah.arub17@gmail.com. Mobile: 085789212539

Cite this as:

'Arub L, Pamungkasari EP, Dewi YLR (2020). Does the Integrated Health Post have Contextual Effect on Exclusive Breastfeeding? A Multilevel Evidence from Karanganyar, Central Java. J Matern Child Health. 5(1): 99109. https://doi.org/10.26911/thejmch.2020.05.01.11

cc) (1) Journal of Maternal and Child Health is licensed under a Creative Commons Attribution-Non Commercial-Share Alike 4.o International License. 
'Arub et al./ Does the Integrated Health Post have Contextual Effect

\section{BACKGROUND}

The Innocent Declaration of 1990 in Florence Italy mandated the importance of campaigning for Breast Milk (ASI) as an important part of efforts to protect, promote and support breastfeeding (Ministry of Health, 2017). Breastfeeding is one of the basic health, development, and survival of children.

The World Health Organization (WHO) and the United Nations Children's Fund (UNICEF) recommend that breastfeeding should begin within the first hour after birth and the baby should exclusively breastfeed for the first 6 months, with continued breastfeeding until 24 months or more (WHO, 2018). The practice of breastfeeding optimally can reduce child mortality and contribute to long-term health (WHO, 2017) and children have strong immunity and optimal development (Zakar et al., 2018).

Globally, the overall rate of exclusive breastfeeding for babies under the age of six months is $40 \%$, with only 23 countries achieving at least $60 \%$ of infants less than six months exclusively breastfed. WHO has set a target to increase the level of exclusive breastfeeding to at least $60 \%$ by 2030 (WHO, 2017).

The coverage of exclusive breastfeeding in Indonesia is $61.33 \%$. This figure has exceeded the 2017 Strategic Plan (Strategic Plan) target of $44 \%$ (Ministry of Health, 2017). The percentage of exclusive breastfeeding for babies 0-6 months in Central Java in 2017 was $54.4 \%$, a slight increase compared to the percentage of exclusive breastfeeding in 2016 which was $54.2 \%$ (Central Java Health Office, 2017). Coverage of exclusive breastfeeding in 2016 in Karanganyar Regency was recorded at $61.1 \%$ or as many as 7,024 babies from the number of infants aged o-6 months totaling 11,488 babies (DHO Karanganyar, 2016).

The low practice of exclusive breastfeeding is influenced by several factors. Jaafar et al. (2016) draws the conclusion that exclusive breastfeeding is influenced by social and cultural factors. According to Asfaw et al. (2015) socio-demographic characteristics including maternal age, educational status (Habibi et al., 2018), occupation (Tewabe et al., 2017) were identified as factors influencing the practice of exclusive breastfeeding. Breastfeeding is a health behavior that is also influenced by social conditions, psychological mother, and social support (Boateng et al., 2019; Mgongo et al., 2019).

Strong family support can increase exclusive breastfeeding. Family support can be in the form of information support, motivating mothers and convincing mothers to give exclusive breastfeeding to their babies (Sipahutar et al., 2019). In addition, the role of social capital also has an influence on one's health behavior. Social capital and health can be seen from various perspectives. A better social capital relationship can be associated with better health outcomes (Ehsan et al., 2019).

\section{SUBJECTS AND METHOD}

\section{Study Design}

This was an observational analytic method with cross sectional approach conducted in 25 posyandu in the working area of the Karanganyar District Health Office from August to September 2019.

\section{Population and Sample}

The population in this study were all breastfeeding mothers in Karanganyar Regency who had babies aged 7 to 12 months and participated in Posyandu. A total of 200 study subjects was selected by stratified random sampling at the posyandu level. This technique was chosen because the author divided the population into strata according to certain characteristics that were considered important namely the posyandu strata includeing pratama, middle, full moon, and independent. A simple random sampling technique was chosen at the individual level. This tech- 
nique was chosen because the author would choose samples at each posyandu in a simple random manner. Samples were selected from 25 posyandu units spread across all strata and then each posyandu selected 8 study subjects.

\section{Study Variables}

The dependent variable was exclusive breastfeeding. The independent variables were maternal age, education, occupation, type of childbirth, knowledge, mother's attitude, family support, and social capital.

\section{Operational Definition of Variables} Exclusive breastfeeding was breastfeeding only without providing food and other drinks except vitamin supplements, minerals, and/or drugs for medical purposes until the baby is 6 months old. The data were collected by questionnaire. The measurement scale was categorical, coded o for no and 1 for yes. Maternal age was the age at the time of the study stated in years. The data were collected by questionnaire. The measurement scale was continuous and transformed into dichotomous, coded o for age $<20$ or $\geq 35$ years and 1 for age 20-35 years.

Education was the highest formal level of education pursued by mothers. The data were collected by questionnaire. The measurement scale was categorical, coded o for $<$ Senior high school and 1 for $\geq$ Senior high school.

Occupation was an activity undertaken other than as a housewife to earn income/ money. The data were collected by questionnaire. The measurement scale was categorical, coded o for working at house and 1 for working outside the house.

Type of birth delivery was the way a mother gives birth to a baby. The data were collected by questionnaire. The measurement scale was categorical, coded o for normal and 1 for section caesarean.

Knowledge was things that are known or unknown to the mother about the definition of exclusive breastfeeding, frequency, benefit, the role of health personnel. The data were collected by questionnaire. The measurement scale was continuous and transformed into dichotomous, coded o for low (score <10) and 1 for high (score $\geq 10$ ).

Attitude was a positive or negative assessment of a mother about exclusive breastfeeding that will affect the mother in giving exclusive breastfeeding to her child. The data were collected by questionnaire. The measurement scale was continuous and transformed into dichotomous, coded o for score $<37$ and 1 for score $\geq 37$.

Family support was support given by members who have marital ties or blood relations in the form of emotional, informational, instrumental, and appraisal. The data were collected by questionnaire. The measurement scale was continuous and transformed into dichotomous, coded o for score $<30$ and 1 for $\geq 30$.

Social capital was a characteristic of the community where mothers live which includes social organization, citizen participation, norms of reciprocity, mutual trust between community members, which facilitates cooperation to achieve mutual benefits. The data were collected by questionnaire. The measurement scale was continuous and transformed into dichotomous, coded o for score $<49$ and 1 for score $\geq 49$.

\section{Data Analysis}

Sample characteristics in continuous data were described in mean, minimum, and maximum. Sample characteristics in continuous data were described in frequency (n) and percent (\%). Bivariate analysis was performed by Chi-square. Multivariate analysis was performed by multilevel multiple logistic regression.

\section{Research Ethic}

This study was conducted based on research ethics, namely informed consent, anonymity, confidentiality, and ethical eligibility. Ethics 
'Arub et al./ Does the Integrated Health Post have Contextual Effect

permit was obtained from the Health Research Ethics Commission at Dr. Moewardi Hospital, Surakarta, Central Java, No. 1053/VIII/HREC/2019.

RESULTS

\section{Sample Characteristics}

Table 1 showed sample characteristics for continuous data. Table 1 showed sample characteristics for categorical data.

Table 1. Sample characteristics for continous data

\begin{tabular}{lccccc}
\hline \multicolumn{1}{c}{ Variables } & n & Mean & SD & Min. & Max. \\
\hline Knowledge & 200 & 10.16 & 1.61 & 6 & 12 \\
Maternal attitude & 200 & 30.35 & 3.86 & 19 & 35 \\
Family support & 200 & 37.42 & 4.27 & 24 & 47 \\
Social Capital & 200 & 49.41 & 2.21 & 42 & 54 \\
\hline
\end{tabular}

Table 2. Sample characteristics for categorical data

\begin{tabular}{|c|c|c|}
\hline Characteristics & Frequency(n) & Percentage (\%) \\
\hline \multicolumn{3}{|l|}{ Age } \\
\hline$<20$ or $\geq 35$ years & 43 & 21.0 \\
\hline 20 to 35 years & 157 & 79.0 \\
\hline \multicolumn{3}{|l|}{ Education } \\
\hline$<$ Senior high school & 47 & 32.5 \\
\hline$\geq$ Senior high school & 153 & 76.5 \\
\hline \multicolumn{3}{|l|}{ Occupation } \\
\hline Working at home & 157 & 78.5 \\
\hline Working outside home & 43 & 21.5 \\
\hline \multicolumn{3}{|l|}{ Type of birth delivery } \\
\hline Normal & 155 & 77.5 \\
\hline Sectio cesarea & 45 & 22.5 \\
\hline \multicolumn{3}{|l|}{ Maternal Knowledge } \\
\hline Poor $($ score < 10) & 55 & 27.5 \\
\hline Good (score $\geq 10$ ) & 145 & 78.5 \\
\hline \multicolumn{3}{|c|}{ Attitude toward exclusive breastfeeding } \\
\hline Negative (score <37) & 61 & 30.5 \\
\hline Positive (score $\geq 37$ ) & 139 & 69.5 \\
\hline \multicolumn{3}{|l|}{ Family Support } \\
\hline Weak (score <30) & 51 & $25 \cdot 5$ \\
\hline Strong (score $\geq 30$ ) & 149 & 74.5 \\
\hline \multicolumn{3}{|l|}{ Social Capital } \\
\hline Weak (score <49) & 55 & 27.5 \\
\hline Strong (score $\geq 49$ ) & 145 & 72.5 \\
\hline
\end{tabular}

Table 2 showed 79.0\% mothers aged 20 to 34 years, maternal education $\geq$ Senior high school birth normally were 155 (77.5\%). Mothers with high knowledge were $72.5 \%$. Positive maternal attitude were $69.5 \%$. Mothers with strong family support were 149 (74.5\%). Mothers with strong social capital were 145 (72.5\%).was 153 (76.5\%), and mothers who gave birth normally were 155 (77.5\%). Mothers with high knowledge were $72.5 \%$. Posi- tive maternal attitude were $69.5 \%$. Mothers with strong family support were 149 (74.5\%). Mothers with strong social capital were 145 (72.5\%).

\section{Bivariate analysis}

Table 3 showed results of Chi square test on the effect of age, education, occupation, type of delivery, knowledge, attitude, family support, and social capital on exclusive breastfeeding. 
Mothers aged 20 to 34 years (88.0\%) gave more exclusive breastfeeding than mothers aged $<20$ or $\geq 35$ years ( $46.5 \%$ ).

There was an influence of maternal education on exclusive breastfeeding. Mother with education $\geq$ Senior high school (90.0\%) give more exclusive breastfeeding than those with education $<$ Senior high school (45.0\%).

There was an influence of maternal occupation on exclusive breastfeeding. Mothers who work outside the house (35.0\%) provide less exclusive breastfeeding than those who work at home (92.0\%).

There was an effect of the type of delivery on exclusive breastfeeding. Mothers who delivered section caesarean (51.0\%) gave less exclusive breastfeeding than mothers who gave birth normally (87.1\%). There was an influence of maternal knowledge on exclusive breastfeeding. Mothers with good knowledge (88.0\%) gave more exclusive breastfeeding than those with poor knowledge (56.0\%). There was an influence of maternal attitude towards exclusive breastfeeding. Mothers with positive attitudes related to exclusive breastfeeding $(87.0 \%)$ gave more exclusive breastfeeding than mothers with negative attitudes (55.0\%).

There was an influence of family support for exclusive breastfeeding. Mothers with strong family support (89.0\%) gave more exclusive breastfeeding than mothers with weak family support (56.0\%). There is an influence of social capital on exclusive breastfeeding. Mothers with strong social capital (91.0\%) gave more exclusive breastfeeding than mothers with weak social capital (47.0\%).

Table 3. Chi square test on the effect of age, education, occupation, type of delivery, knowledge, attitude, family support, and social capital on exclusive breastfeeding

\begin{tabular}{|c|c|c|c|c|c|c|c|}
\hline \multirow{3}{*}{$\begin{array}{l}\text { Independent } \\
\text { Variables }\end{array}$} & \multirow{3}{*}{ Category } & \multicolumn{4}{|c|}{ Exclusive breastfeeding } & \multirow{3}{*}{$\mathbf{O R}$} & \multirow{3}{*}{$\mathbf{p}$} \\
\hline & & \multicolumn{2}{|c|}{ No } & \multicolumn{2}{|c|}{ Yes } & & \\
\hline & & $\mathbf{n}$ & $\%$ & $\mathbf{n}$ & $\%$ & & \\
\hline \multirow[t]{2}{*}{ Age } & $<20$ or $\geq 35$ years & 23 & 53.5 & 20 & 46.5 & 8.53 & $<0.001$ \\
\hline & 20-34 y & 19 & 12.0 & 138 & 88.0 & & \\
\hline \multirow[t]{2}{*}{ Education } & $<$ Senior high school & 26 & 55.0 & 21 & 45.0 & 10.60 & $<0.001$ \\
\hline & $\geq$ Senior high school & 16 & 10.0 & 137 & 90.0 & & \\
\hline \multirow[t]{2}{*}{ Occupation } & Working at home & 12 & 8.0 & 142 & 92.0 & 0.04 & $<0.001$ \\
\hline & Working outside house & 30 & 65.0 & 16 & 35.0 & & \\
\hline \multirow{4}{*}{$\begin{array}{l}\text { Types of child } \\
\text { delivery } \\
\text { Education }\end{array}$} & Normal & 20 & 12.9 & 135 & 87.1 & 0.06 & $<0.001$ \\
\hline & Sectio cesarea & 22 & 49.0 & 23 & 51.0 & & \\
\hline & Poor (score <10) & 24 & 44.0 & 31 & 56.0 & $5 \cdot 46$ & $<0.001$ \\
\hline & Good (score $\geq 1$ & 18 & 12.0 & 127 & 88.0 & & \\
\hline \multirow[t]{2}{*}{ Attitude } & Negative (score <37) & 23 & 45.0 & 28 & 55.0 & 5.62 & $<0.001$ \\
\hline & Positive (score $\geq 37$ ) & 19 & 13.0 & 130 & 87.0 & & \\
\hline \multirow[t]{2}{*}{ Family support } & Weak (score <30) & 27 & 43.0 & 36 & 57.0 & 6.10 & $<0.001$ \\
\hline & Strong (score $\geq 30$ ) & 15 & 11.0 & 122 & 89.0 & & \\
\hline \multirow[t]{2}{*}{ Social capital } & Weak (score <49) & 29 & 53.0 & 26 & 47.0 & 9.51 & $<0.001$ \\
\hline & Strong (score $\geq 49$ ) & 13 & 9.0 & 132 & 91.0 & & \\
\hline
\end{tabular}


'Arub et al./ Does the Integrated Health Post have Contextual Effect

\section{The result of multilevel multiple logistic regression analysis}

Table 4 showed the results of a multilevel multiple logistic regression tests of contextual effect of integrated health post on exclusive breastfeeding. Table 4 shows exclusive breastfeeding increasing with maternal age between $20-34$ years $(\mathrm{b}=2.38$; $95 \% \mathrm{CI}=$ 0.62 to $4.15 ; \mathrm{p}=0.008)$, maternal education $\geq$ Senior highs school $(b=1.64 ; 95 \% \mathrm{CI}=0.01$ to $3.23 ; \mathrm{p}=0.049)$, good knowledge $(\mathrm{b}=2.13$; $95 \% \mathrm{CI}=0.41$ to $3.86 ; \mathrm{p}=0.015$ ), positive attitude toward exclusive breastfeeding $(\mathrm{b}=$ $1.67 ; 95 \% \mathrm{CI}=0.10$ to $3.23 ; \mathrm{p}=0.036)$, strong family support $(b=1.58 ; 95 \% \mathrm{CI}=0.10$ to 3.07; $\mathrm{p}=0.036)$, and strong social capital $(\mathrm{b}=$ $1.64 ; 95 \% \mathrm{CI}=0.01$ to $3.27 ; \mathrm{p}=0.049$ ). Exclusive breastfeeding decreased with mother who worked outside the home $(b=-3.54$; $95 \% \mathrm{CI}=-5.50$ to $-1.58 ; \mathrm{p}<0.001)$ and section cesarean $(b=-1.88 ; 95 \% \mathrm{CI}=-3.58$ to $-0.19 ; \mathrm{p}$ $=0.029$ ).

There was a contextual effect of integrated health post on exclusive breastfeeding with intra-class correlation $($ ICC $)=29.3 \%$.

\section{DISCUSSION}

1. The effect of maternal age on exclusive breastfeeding

The results of this study showed the effect of maternal age on exclusive breastfeeding. Hossain et al. (2018) identified several sociodemographic factors associated with exclusive breastfeeding in Bangladesh. Mothers between the ages of 15 and 19 are almost 0.34 times less likely to exclusively breastfeed their babies. In line with the cross-sectional study conducted in the city of Londrina-PR in 770 children under 12 months had a significant relationship between exclusive breastfeeding and maternal age, showing that adolescent mothers were more likely not to breastfeed their children exclusively than mothers aged between 20 and 25 years old. In addition, exclusive breastfeeding decreases in those aged 35 years and over (Sauza et al., 2012).

Raheel and Tharkar's (2018) stated that mothers aged 35 to 49 years are found to be less likely to give exclusive breastfeeding compared to younger mothers. This negative effect may be because many mothers tend to use their own experiences rather than what they have learned from the clinic, or health personnel. Older mothers have given birth many times, so it is possible that they follow whatever they have practiced before without considering the new messages taught in the clinic or health personnel.

\section{The effect of education on exclusive breastfeeding}

Several studies conducted on exclusive breastfeeding show significant results between maternal education and exclusive breastfeeding. Educated mothers are more receptive to health information especially concerning their children, therefore they are more likely to realize the importance of exclusive breastfeeding and are more willing to practice it (Boateng, 2018); Mohammed et al., 2014).

The results of this study have the effect of education on exclusive breastfeeding. Improved education often allows mothers to make wise decisions about breastfeeding practices for children. Thus, a higher level of maternal education can be a good estimate of success in exclusive breastfeeding practices (Mosquera et al., 2019).

\section{The effect of occupation on exclusive breastfeeding}

There was an influence of maternal occupation on exclusive breastfeeding. Mothers who work outside the home reduce exclusive breastfeeding. Tadessa et al. (2019) stated that mothers who do not work were 26 times more likely to practice exclusive breastfeeding compared to working mother.

Many reasons can be stated for the relationship of working mothers with low exclusive breastfeeding. In accordance with the 
Constitution of Ethiopia and Labor Proclamation, female workers are entitled to maternity leave fully paid for 90 days (30 days before birth and 60 days after birth). Therefore, working mothers will have a maximum of two or three months to stay at home and breastfeed their babies. This is not in accordance with the six month period of exclusive breastfeeding recommended by WHO. Short periods of leave, respectively, influence mothers to introduce supplementary feeding from the moment they return to work (Tadesse et al., 2019).

A work environment that is not friendly to nursing mothers such as the unavailability of facilities for breastfeeding at work, mothers who are employed cannot bring their babies to work and breastfeed there, is one of the reasons working mothers do not give exclusive breastfeeding to their babies.

In line with study conducted by Soomro (2015), stating that the reason working mothers cannot provide exclusive breastfeeding is because the place where the working mothers do not provide facilities that support breastfeeding such as lactation rooms, bottles, or refrigerators where breastfeeding is stored. In line with the provision of adequate breastfeeding facilities in the workplace, such as the room where breastfeeding is, and the refrigerator, and the existence of a policy that allows mothers to have flexible time to express breast milk, is an important determinant for exclusive breastfeeding among employed mothers.

\section{The effect of type of baby delivery on exclusive breastfeeding}

The results of this study indicate that there is a relationship between the type of delivery and exclusive breastfeeding. Onah et al. (2014) stated that mothers who gave birth by caesarean section were 0.38 times less likely to breastfeed their infant exclusively compared to those who gave birth per vaginam. Mothers who give birth by cesarean section usually take a long time to recover from the effects of anesthesia before thinking about the recommended infant feeding practice of breast milk. The problem of increasing maternal stress after delivery by caesarean section can also delay the time to breastfeed the baby directly.

\section{The effect of knowledge on exclusive breastfeeding}

The results of this study have the effect of mother's knowledge on exclusive breastfeeding. Tsegaye et al. (2019) reported that children of mothers who have good knowledge of exclusive breastfeeding practices are twice as likely to give exclusive breastfeeding $(\mathrm{aOR}=2.3 ; 95 \% \mathrm{CI}=1.6$ to 3.5$)$ compared to children of mothers who have poor knowledge about the practice of exclusive breastfeeding. Lack of knowledge about the benefits of breastfeeding has been reported to contribute to the low practice of exclusive breastfeeding in Sub-Saharan Africa and rural areas in Ghana (Boateng, 2018; Mogre et al., 2016)

Knowledge about breastfeeding is the most influential variable on exclusive breastfeeding (Zhang et al., 2018). Mothers who do not know about the benefits of breastfeeding, especially exclusive breastfeeding, will have an impact on the failure of exclusive breastfeeding itself. Especially with the excessive promotions of formula milk for the good of the children, it will make mothers even more hesitant to give exclusive breastfeeding. Good knowledge will provide experience for mothers to breastfeed exclusively, because it will provide a sense of trust and separate attitudes for mothers to breastfeed their babies, so there is a relationship between the knowledge of the giving of exclusive breastfeeding (Wowor et al, 2013).

\section{The effect of attitude towards exclu- sive breastfeeding}

There is an influence of mother's attitude towards exclusive breastfeeding in this study. A study by Wowor et al. (2013) indicated that 
there was a relationship between maternal attitudes toward exclusive breastfeeding. The positive attitude of the mother towards exclusive breastfeeding makes it possible to form the basis of the mother's decision in exclusive breastfeeding. Behavioral beliefs are the beliefs that mothers have in considering the advantages and disadvantages felt by mothers to have the intention to give exclusive breastfeeding (Boateng, 2018).

\section{The effect of family support on exclusive breastfeeding}

Breastfeeding is a health behavior that is not only influenced by physiological factors but also on the social and psychological conditions of the mother (Mgongo et al., 2019). The results showed that family support especially the husband played an important role during breastfeeding. Mothers who get family support succeed in providing exclusive breastfeeding compared to mothers who do not get family support (Maramis et al., 2017).

Family support can be in the form of information support, motivation for mothers to be able to provide exclusive breastfeeding to their babies, provide adequate nutrition to mothers and families involved in homework, so that nursing mothers are more focused on caring for their babies without being burdened with the usual homework (Sipahutar, 2019).

\section{The effect of social capital on exclu- sive breastfeeding}

The results of this study indicate that there is an influence of social capital on exclusive breastfeeding. Social capital and health have been approached from various interrelated perspectives. Having a good social capital relationship is associated with better health outcomes. But social capital can also have a negative relationship with health (VillalongaOlives and Kawachi, 2015; Moore and Kawachi, 2017).

Poor quality environments, such as the absence of a support system to encourage mothers to start breastfeeding, and perhaps the influence of family or friends who give formula milk to their babies, is the norm that can prevent the practice of exclusive breastfeeding. In addition, the lack of or insufficient support from institutional support systems including health care providers also influences the practice of exclusive breastfeeding (Edwards et al., 2017).

\section{The effect of integrated health post on exclusive breastfeeding}

There is an influence of integrated health post on exclusive breastfeeding. A study by Lestari (2019) showed integrated health post had contextual influence on exclusive breastfeeding. Integrated health post was an increase in the quality of human resources from an early age through social services in the community that support development. One of the roles of cadres in integrated health post is to provide services and improve the quality of services, information, education and health motivation for breastfeeding mothers in implementing posyandu (Saputri and Rahman, 2018).

\section{AUTHOR CONTRIBUTION}

Lathifah Arub as the main autor played roles in carrying out study, collecting data, formulating articles, and processing the data. Eti Poncorini Pamungkasari played a role in preparing the background and analyzing data. Yulia Lanti Retno Dewi played a role in the formulation of the mindset and discussion.

\section{CONFLICT OF INTEREST}

There is no conflict of interest in this study.

FUNDING AND SPONSORSHIP

This study is self-funded.

ACKNOWLEDGEMENT

Acknowledgments were conveyed by author to the Head of the Karang-anyar Regency 
'Arub et al./ Does the Integrated Health Post have Contextual Effect

Office. We also thank all mothers who have been willing and cooperative to be the subject of study.

\section{REFERENCE}

Abasiattai AM, Etukumana EA, Nyong E, Eyo UE (2014). Knowledge and practice of exclusive breastfeeding among antenatal attendees in Uyo, Southern Nigeria. Gaziantep Medical Journal. 20(2):130-135. doi:10.5455/GMJ-3045779.

Alamirew MW, Bayu NH, Birhan Tebeje N, Kassa SF (2017). Knowledge and attitude towards exclusive breast feeding among mothers attending antenatal and immunization clinic at Dabat $\mathrm{He}-$ alth Center, Northwest Ethiopia: A Cross-Sectional Institution Based Study. Nurs Res Pract. 2017: 6561028. doi: 10.1155/2017/6561028.

Asfaw MM, Argaw MD, Kefene ZK (2015). Factors associated with exclusive breastfeeding practices in Debre Berhan District, Central Ethiopia: A cross sectional community based study. Int Breastfeed J. 2015: 1-9. doi:10.1186/s13006-015-0049-2

Boateng GO, Martin SL, Collins SM, Natamba BK, Young SL (2018). Measuring exclusive breastfeeding social support: Scale development and validation in Uganda. Matern Child Nutr. 14(3):1-24. doi:10.1111/mcn.12579.

Boateng MF (2018). Knowledge, attitude and practice of exclusive breast feeding among mothers in Techiman, Ghana Master's thesis. University of Eastern Finland. Retrieved from http://urn.fi/urn:nbn:fi:uef20180869

Dennis CL, Gagnon A, Van Hulst A, Dougherty $G$ (2012). Predictors of breastfeeding exclusivity among migrant and Canadian-born women: Results from a multi-centre study. Matern Child Nutr.
10(4): 527-544. doi:10.1111/j.17408709.2012.00 442.x.

Ehsan A, Klaas HS, Bastianen A, Spini D (2019). Social capital and health: A systematic review of systematic reviews. SSM Popul Health. 7(8): 100425. doi: 10.1016/j.ssmph.2019. 100425.

Habibi M, Zahra F, Aguenaou H, Doukkali L, Mrabet M, Barkat A The impact of maternal socio-demographic characteristics on breast feeding knowledge and practices: An experience from Casablanca, Moroc co. Int J Pediatr Adolesc Med. 5(2): 39-48. doi.org/10.1016/j.ijpa-m.2018.01.003

Hossain M, Islam A, Kamarul T, Hossain G. (2018). Exclusive breastfeeding prac tice during first six months of an infant's life in Bangladesh: A country based cross-sectional study. BMC Pediatr. 18(1): 1-9. https://doi.org/10.1186/s12887-018-1076-0.

Jaafar SH, Ho JJ, Jahanfar S, Angolkar M (2016). Effect of restricted pacifier use in breastfeeding term infants for increasing duration of breast feeding. Cochrane Database Syst Rev. 30(8): CDoo7202. doi:10.1002/14651858.CDoo7202.pub4.

Ministry of Health (2017). Pedoman penyelenggaraan pekan asi sedunia tahun 2017 (Guidelines for organizing the 2017 breastmilk World Week). Jakarta. Retrieved from http:// kesmas.kemkes.go.id/portal/kkonte/ rilis-berita/o72615-pedoman-penyelenggaranpekan-asi-sedunia-ta hun-2017

Lestari E, Pamungkasari EP, Dewi YLR (2019). Multilevel analysis on the contextual effect of posyandu on exclusive breastfeeding in Sleman, Yogyakarta. J Matern Child Health. 4(4): 250-259. https://doi.org/10.26911/thejmch.2019.04.04.04.

Mgongo M, Hussein TH, Stray-Pedersen B, 
'Arub et al./ Does the Integrated Health Post have Contextual Effect

Vangen S, Msuya SE, Wandel M (2019). Facilitators and barriers to breastfeeding and exclusive breast feeding in Kilimanjaro Region, Tanzania: A qualitative study. Int J Pediatr. 2019: 8651010. doi: 10.1155/2019/86510102019;2019.

Mogre V, Dery M, Gaa PK (2016). Knowledge, attitudes and determinants of exclusive breast feeding practice among Ghanaian rural lactating mothers. Int Breastfeed J. 11(1): 1-8. doi: 10.1186/s13006-016-0071-z.

Mohammed ES, Ghazawy ER, Hassan EE (2014). Knowledge, attitude, and practices of breastfeeding and weaning among mothers of children up to 2 years old in a rural area in El-Minia Governorate, Egypt. J Family Med Prim Care. 3(2): 136-140. doi:10.4103/22494863.137639.

Moore S, Kawachi I (2017). Twenty years of social capital and health research: A glossary. J Epidemiol Community Health. 71(5): 513-517. doi:10.1136/jech-2016-208313

Mosquera PS, Lourenço BH, Gimeno S, Malta MB, Castro MC, Cardoso MA, MINA-Brazil Working Group (2019). Factors affecting exclusive breastfeeding in the first month of life among Amazonian children. PloS ONE. 14(7): 1-16. doi: 10.1371/journal.pone.0219801.

Onah S, Osuorah DI, Ebenebe J, Ezechukwu C, Ekwochi U, Ndukwu I (2014). Infant feeding practices and maternal sociodemographic factors that influence practice of exclusive breastfeeding among mothers in Nnewi South-East Nigeria: A cross-sectional and analytical study. Int Breastfeed J. 9(1):1-10. doi:10.1186/1746-4358-9-6.

Soomro JA, Shaikh ZN, Bijarani SA, Saheer TB(2015). Factors affecting breast- feeding practices in working women of Pakistan. East Mediterr Health J. 22(11): 810-816. Retrieved from http://applications.emro.who.Int/EMHJ/v22/11/EMHJ_2016_22_11_810_816 .pdf.

Souza SNDH, Migoto MT, Rossetto EG, Mello DF (2012). Prevalence of breastfeeding and associated factors in the municipality of Londrina (PR, Brazil). Acta Paul Enferm. 25(1): 29-35. http://doi.org/10.1590/So103-21 002012 000100006. 25(1):29-35.

Sipahutar S, Lubis NL, Siregar FA (2019). The association between maternal knowledge, family support, and exclusive breastfeeding in Siborong Borong Community Health Center, North Tapanuli, North Sumatera. J Matern Child Health. 4: 338-341. https://doi.org/10.26911/thejmch.2019.04.05.06

Tadesse F, Alemayehu Y, Shine S, Asresahegn H, Tadesse TT (2019). Exclusive breastfeeding and maternal employment among mo-thers of infants from three to five months old in the Fafan zone, Somali regional state of Ethiopia: A com-parative cross-sectional study. BMC Public Health. 19: 1015. doi: 10.1186/ s12889-019-7345-5.

Tewabe T, Mandesh A, Gualu T, Alem G, Mekuria G, Zeleke H (2017). Exclusive breastfeeding practice and associated factors among mothers in Motta town, East Gojjam zone, Amhara Regional State, Ethiopia, 2015: A cross-sectional study. Int Breastfeed J. 27 (12): 1-7. doi: 10.1186/s13006-017-0103-3.

Tiyas DW, Murti B, Indarto D (2016). Qualitative analysis on the factors affecting exclusive breastfeeding among working mothers at community health center in Bangkalan, Madura. J Matern Child Health. 1(2): 110-118. https://doi.org/10.26911/thejmch.2016.01.02.06. 
Tsegaye M, Ajema D, Shiferaw S, Yirgu R (2019). Level of exclusive breast feeding practice in remote and pasto-ralist community, Aysaita woreda, Afar, Ethiopia. Int Breastfeed J 6: 1-15. doi: 10.1186/s13006-019-0200 -6.

Villalonga-Olives E, Kawachi I (2015). The measurement of bridging social capital in population health research. Health Place. 36(2015): 47-56. doi: 10.1016/j.healthplace.2015.09.02.

World Health Organization (2017a). Breastfeeding. Health topics. Retrieved from https://www.who.int/to- pics/breastfeeding/en/.

World Health Organization (2017b). World breastfeeding week. World Health Organization. Retrieved from http://worldbreastfeedingwe-ek.org/2017/downloads-por.shtml.

World Health Organization (2018a). Maternal, newborn, child and adolescent health. World Health Or-ganization. Retrieved from http://www.who.int/maternal_child_adolescent/topics/ne wborn/nutrition/breastfeeding/en/.

World Health Organization (2018b). Guideline: counseling of women to improve breastfeeding practices. Geneva: World Health Organization; 20-18. Licence: CC BY-NC-SA 3.0 IGO. Retrieved from https://www.who.int/nutrition/publications/guidelines/counsellingwomen-improve-bfpractices/ en/.

Wowor M, Laoh JM, Pangemanan DHC (2013). Hubungan pengetahuan dan sikap dengan pemberian ASI eksklusif pada ibu menyusui di Puskesmas Bahu Kota Manado (Relationship between knowledge and attitude with exclusive breastfeeding for breastfeeding mothers at Manado City Health Center). E jurnal Keperawatan. 1(1): 77-88. Retrieved from https://ejournal.unsrat.ac.id/in dex.php/jkp/article/view/2199.

Zakar R, Zakar MZ, Zaheer L, Fischer F (2018). Exploring parental percep-tions and knowledge regarding breast feeding practices in Rajanpur, Punjab Province, Pakistan. Int Breastfeed J. 3(13): 24. doi:10.1186/s13006-0180171-Z.

Zhang Z, Zhu Y, Zhang L, Wan H (2018). What factors influence exclusive breastfeeding based on the theory of planned behaviour. Midwifery. 62: 177182. doi:10.1016/j.midw.2018.04.006. 